\title{
SOME FEATURES OF THE STRUCTURE OF A FLYING FEATHER DOMESTIC GOOSE (Anser anser)
}

\section{WYBRANE WŁAŚCIWOŚCI BUDOWY PIÓR LOTNYCH UDOMOWIONEJ GĘSI GĘGAWEJ (Anser anser)}

Department of Anatomy of Animals, National University of Life and Environmental Sciences of Ukraine, Kyiv, Ukraine

\begin{abstract}
Streszczenie. Określono liczbę prostych piór ogonowych i wszystkie rodzaje piór lotnych umieszczonych na skrzydłach gęsi gęgawej. Opisano właściwości makro- i mikrobudowy oraz wskazano niektóre morfometryczne parametry struktur piór lotnych przy skrzydle oraz ogonie lotki, kieszeń miazgi, szypułki pióra lotnego i sterówki. Ustalono, że rdzeń osi pióra ptasiego jest niejednorodny. Większe jego obszary wraz z zawartością pierścieni piór tworzą szkielet kratownicy. Ustalono, że gałęzie pióra lotki są ze sobą połączone nie tylko poprzez szypułki pióra lotnego, lecz również poprzez grzbiet przyosiowy.
\end{abstract}

Key words: flight feathers, steering feathers, stroke feathers.

Słowa kluczowe: pióra lotne, pióra sterówki, pióra lotki.

\section{INTRODUCTION}

According to an anatomic nomenclature (Baumel et al. 1993) a common contour feathers is divided by a flight feathers (pennae volatus) and integumentary feathers (pennae tectrices). The flight feathers belong steering feathers (or rectrices) and stroke feathers (or remiges) which are located under the tail and wings of birds.

However the general laws of the feathers' structure of some birds are highlighted in the literature. However certain structural features of feathers structures remain uncertain today. In particular there are no dictates on the internal structure stem of feather (or rhachis pennae), structural features and accommodation barbules pennae at the proximal and distal branches flight feathers, morphilogical features pulp that is situated in calamus etc. It is discovered that the branches of feathers (or rami pennae) remiges are interconnected with each other not only by barbules of feather but also with ventral ridge.

\section{MATERIAL AND METHODS}

Material for research was flight feathers of domestic goose. It was investigated was remiges and rectrices of three adults (under 2 years age) birds - two geese and a gander. To

Corresponding author - Adres do korespondencji: Volodymyr K. Kostiuk, Department of Anatomy of Animals National University of Life and Environmental Sciences of Ukraine, Side-street Sil's'kohospodars'kyy, 1 apt. 24, 03041 Kyiv, Ukraine, e-mail: kvk21@mail.ru 
achieve the objectives common morphological methods were used - macroscopic, microscopic, morphometric. To determine the internal structure of rhachis flight feathers computed tomography research.

\section{RESULTS AND DISCUSSION}

Flight feathers (remiges and rectrices) according to structure is a classic contour feather. Rectrices flight feather - this is feather tail or tail feathers. Tail of domestic goose form 14 rectrices feather, calamus that are deep in the thickness of the skin in the area of the coccyx and a large fan (or vexillum) is asymmetrical. Stroke feathers are situated in wing. Depending on topography and sizes of its share in the stroke feathers it is divided into wing and stroke feathers of the first, second and third order, what accordingly is the basis of brush, forearm and shoulder. Stroke feathers wings are usually represented by three feathers of the small size, attached to the bone bases wing thumb or first thoracic limbs (wings). The feathers of the first order is the longest and the third order is a short remiges feather. The wing of the domestic goose has got 10 tail feathers of the first, 17 - of the second and 6 tail feathers of third order.

Each rectrices and remiges tail feather has a solid, elastic (firm), thick enough bar of feather (or scapus pennae) in which well distinguished two parts - calamus and rhachis pennae are presented.

Calamus remiges of tail feather is a hollow tube from round to oblong oval shape in dorsoventral the direction of the cross sectional shape. The ratio of the outer diameter calamus to the thickness of its wall ranges from $33: 1$ to $12: 1$ (the average is $22: 1$ ). Inside calamus is pulp case (or galerus pulposus) which represents the hole in the form of continuous series of thin-walled, wrinkled, almost transparent, inserted one into the other glass, segments with convex in the direction to the top of feathers bottom. The last distal segment (the geass) of galerus pulposus is attached to the inclined proximal end of the scapus (Fig. 1). Proximal end pulp case (or galerus pulposus) is attached the inner surface of the wall calamus around the lower (proximal) end the of namely. The length of the first proximal segments of pulposus colica almost twice less than its width. In the distal direction the length of the segments increases, exceeding their width 2.0-2.5 times.

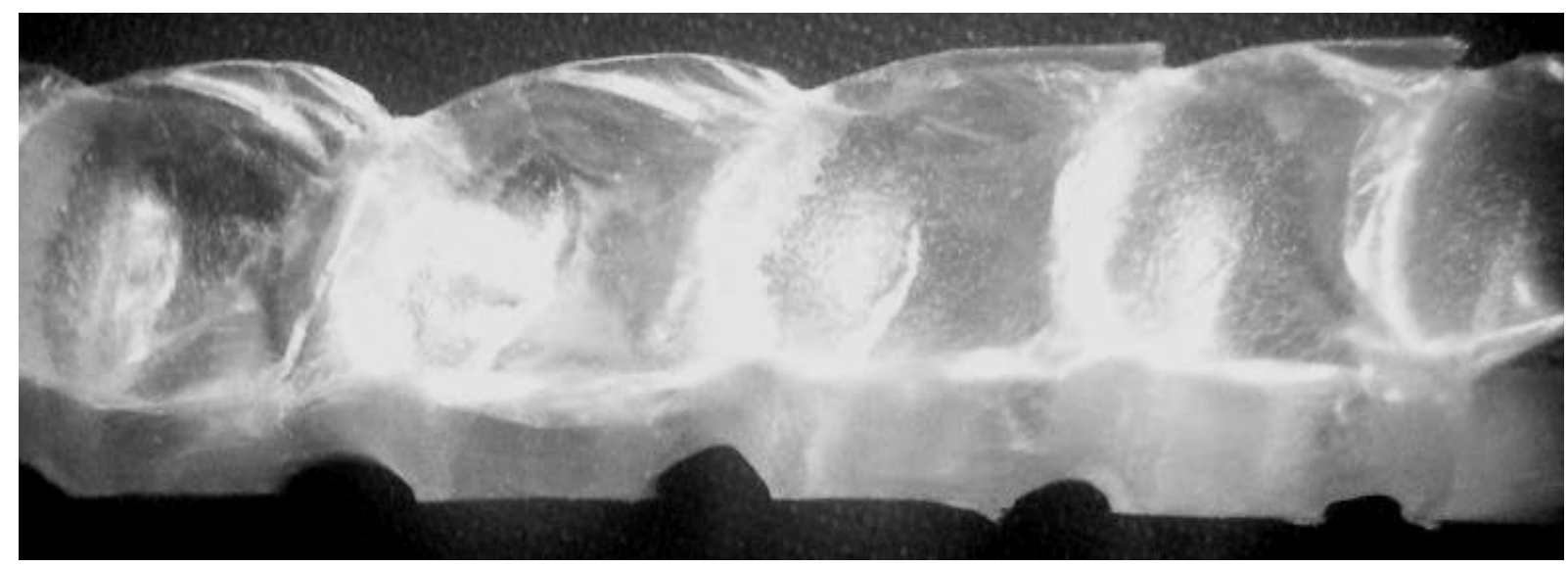

Fig. 1. It's a pulp case rectrices feathers of a goose. Increase 1 x 8 . Left longer (distal) segments, right its shorter (proximal) segments

Ryc. 1. Kieszeń miazgowa lotki gęsi gęgawej. Powiększenie 1 x 8 . Z lewej: dłuższe segmenty (usytuowane dalej od centrum), z prawej: krótsze segmenty (usytuowane bliżej centrum) 
Cells pulp case feather during its development and growth have a direct relationship with the papilla feathers to which actually thicker skin fit blood vessels. Come thus, the pulp case is replies to all structures of the feathers with nutrients during its growth. Feathers that grow in pulp case are visibly filled with blood vessels and capillaries. After the cessation of cell growth feathers pulp case die in consequence of which it turns to the dry light stand with numerous interceptions, placed inside calamus, as indicated by other authors (Baumel et al. 1993; Bulakhov et al. 2009).

Rhachis of flight feathers is a continuation of calamus but in contrast the rhachis doesn't contain a cavity. Inside rhachis is situated the medulla which is represented by the keratin with a large number of micro air bubbles. The domestic goose and other birds the area of calamus in the rhachis has a form of a bevel. That is on the dorsal surface feathers calamus is longer and on the ventral surface is shorter. The rhachis of the feather on the contrary is longer and is shorter - on the dorsal. The proximal end of the rhachis of the feathers on its ventral surface forms two small cloves, with the size from $3.0 \mathrm{~mm}$ to $5.00 \mathrm{~mm}$. Between these closes at a distance of $5.0-6.0 \mathrm{~mm}$ from their tops, is the distal belly button. In opposite directions away from the rhachis branches walk form a large fan. The first (proximal) branches of the large fan are branched off at the beginning of the rhachis on both sides of the distal belly button. Usually these branches are down because their barbules don't have a structure that bonds the branches together. All the branches are soft easily bent in any direction. They have a round cross-sectional shape except for a small initial part of them. At the point of branching from the stalk down the branches are flattened laterally the cross-sectional shape as branches of the contour part large fan. The proximal fur part of the large fan flight feather are small - from a few millimeters to $1 \mathrm{~cm}$, what folds from 3.2 to $6.0 \%$ (average $4.8 \%$ ) of the total length of the large fan.

The distal part of the large fan which is more than $95 \%$ of the entire length of the large fan is formed by branches of the contour type. They are located in one plane in parallel to each other they are rigid and are tapered from the sides of the cross-sectional shape. The height of the branches of feathers (the average is $1000 \mu \mathrm{m}$ ) than the width (averaging about $50 \mu \mathrm{m}$ ) to 20 times (Fig. 2). The proximal barbules of the branches flying feathers have numerous shoots in the form of spines of different lengths. Distal barbs have processes of various shapes of spines, hook, eye-lash others, by which they interlock with the proximal barbs of next branch. Thanks to the grip of the barbs and branches among themselves it the large fan part of the webs of the flying feathers has got the form of blades or paddles, which provides a bird's flight. The branches of flights feathers of domestic goose have a substantial difference of structure and form. It lies in the fact that the proximal end of each branch (its length is from one third to one half of the total length of branches) has a very thin, elongated and distally curved ventral ridge (Fig. 2). It consists only of transparent cortical substance and has the appearance of a slim glossy transparent plastic or cellophane film, which adheres to the same ventral edge of the opposite distal branches. This elongated and distally curved comb have branches of both external and internal webs. As a result, some of the webs of the feathers is almost hermetically closed with the ventral surface. Obviously this feature of the structure of the pen protects it from penetration of water and forms the particular airbag, which has not only a thermal or thermoregulatory function, but easily pushes the bird's body 
on the surface of the water after diving for its prey. It's obvious that this kind of tape covers the fan on the bottom of the pen against ingress of water during cleanse of these species of waterfowl from the water surface when the wings with a certain force hit the water. This feature of the structure of feathers home of the goose is well visible. On the ventral surface of this feather you can see the contour of another, smaller, feathers, glittering, as the curved part of the ventral ridges form an almost continuous mirror surface.

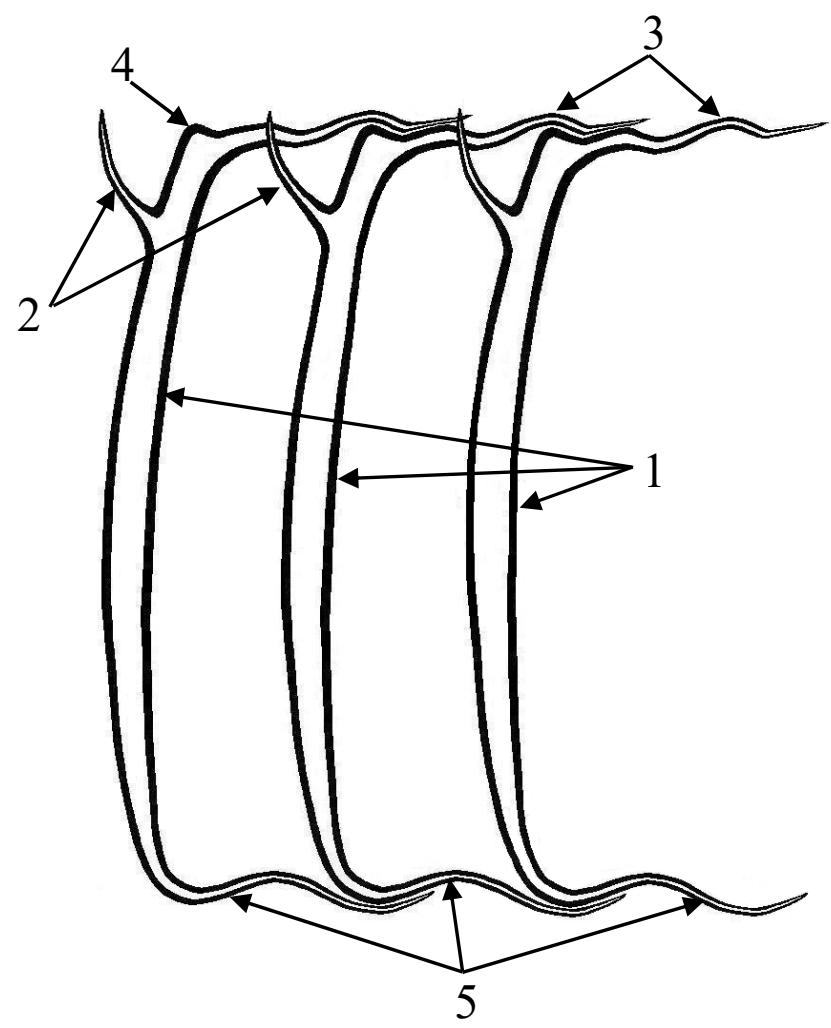

Fig. 2. Scheme of structure of branches of the flight feather of the first order of domestic goose in the cross section. 1 - branches of feathers, 2 - proximal barbules, 3 - distal barbules, 4 - dorsal ridge of branches, 5 - curved ventral ridge of branches

Ryc. 2. Schemat budowy gałęzi pióra lotki pierwszego rzędu gęsi gęgawej w przekroju poprzecznym. 1 - gałęzie pióra, 2 - bliższa szypułka, 3 - dalsza szypułka, 4 - dolny grzbiet gałęzi pióra, 5 - brzusznie zagięte grzbiety gałęzi pióra

The height and width of the stem of feathers of all orders (first, second, third) is almost the same, so that the cross sectional shape of the stem close to round, so in the future these indicators we will call to the «diameter of the stem», although due to the presence of a ventral furrow and the unpaired ventral and paired lateral crest of the ventral ridges (Fig. 3) the cross sectional shape of the stem is not perfectly round. Of course the diameter of the rhachis from its proximal end to the tip of the feathers varies. It is greatest in the proximal part of the rhachis, in the transition region calamus in the rhachis and least in distal part, which is placed at the top of the feather. To obtain certain reliable statistics parameters all morphometric measurements were performed in the middle part of the rhachis, the average diameter of feathers of the first order is $3370.0 \mu \mathrm{m}$, and the second order $-3250.0 \mu \mathrm{m}$. Perfectly round shape of the cross section provides the same structural strength in all perpendicular thereto direction. But what is clear is that the strength and stiffness of the 
rhachis should be more in dorsoventral direction, because during the flight in this direction on the rhachis there are two powerful opposing forces - the force of gravity and the lifting force that is created by the efforts of wing muscles. Great strength and stiffness of the stem feathers in dorsoventral direction are provided with special structures - the ventral ridge, which is located in the ventral furrow and extends along the entire rhachis and two pronounced lateral ridges ventral which limit laterally ventral furrow of the stem (Fig. 3).

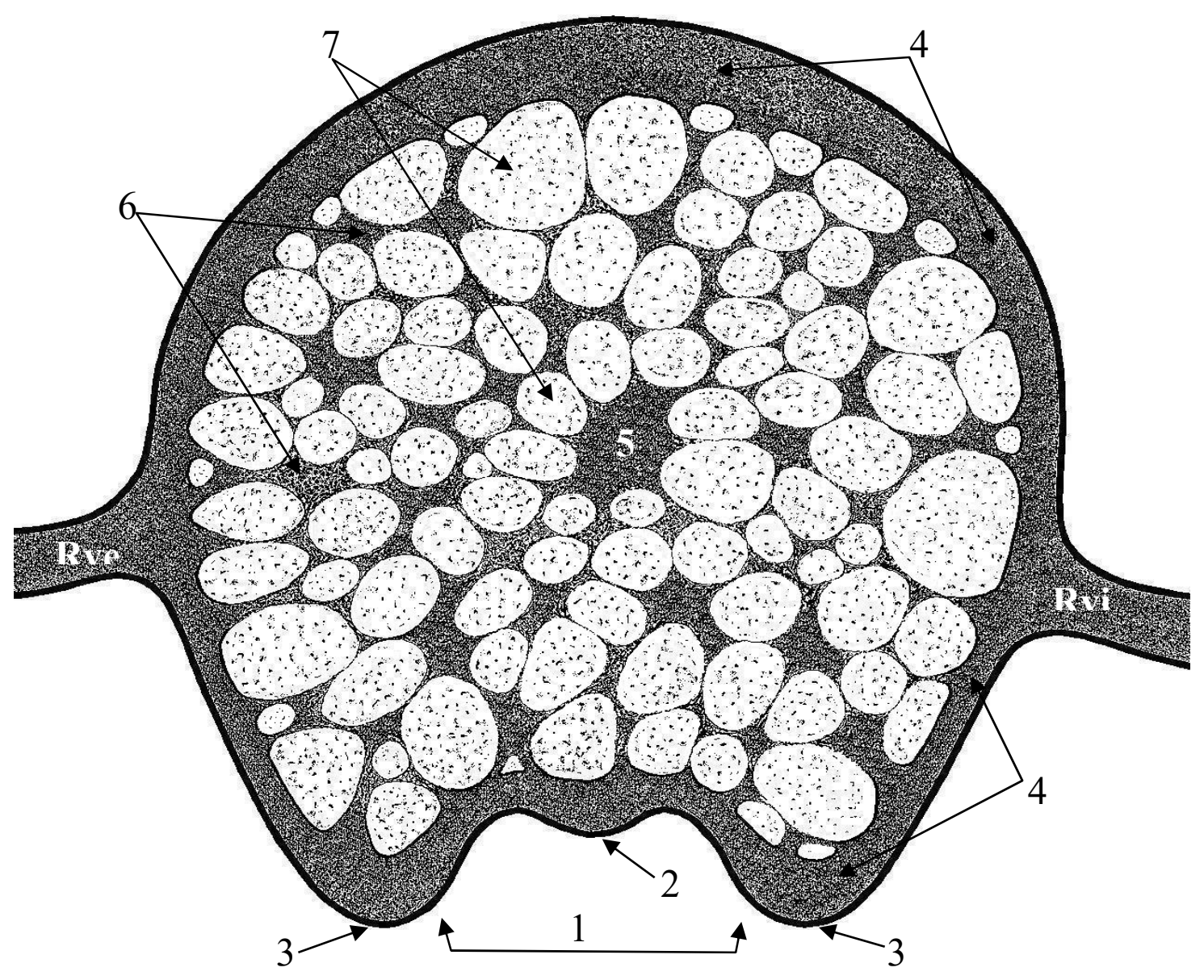

Fig. 3. The scheme of the cross section of the stem of the flight feathers of the second order of domestic goose. Rve - branch of external large fan, Rvi - branch of internal large fan, 1 - ventral furrow of stem, 2 - ventral comb of stem, 3 - lateral ventral combs of stem, 4 - cortical substance of wall of stem, 5 - an accumulation of compact brain substance is along the central axis of stem, 6 - trabeculae of the compact brain substance of stem, 7 - brain substance of stem

Ryc. 3. Schemat przekroju łodyg piór lotnych drugiego rzędu gęsi gęgawej. Rve - gałąź zewnętrznego większego skrzydła, Rvi - gałąź wewnętrznego większego skrzydła, 1 - dolna bruzda trzonu łodygi pióra, 2 - dolny grzebień trzonu łodygi pióra, 3 - boczny dolny grzbiet łodygi pióra, 4 - korygująca substancja ścianki trzonu łodygi pióra, 5 - skupisko istoty spoistej wzdłuż centralnej osi trzonu łodygi pióra, 6 - beleczka istoty spoistej trzonu łodygi pióra, 7 - istota rdzenia trzonu łodygi pióra

The rhachis of the feathers form a cortex and medulla. The cortex of the stem forms a dense outer wall, and the medulla fills the interior lumen of the rhachis. As can be seen from Fig. 3 the thicknesses of the cortical substance are not the same. The thickest is the dorsal wall of the rhachis and the wall of the paired lateral and unpaired ventral ridges (Fig. 3). 
The average wall thickness of the stem in these areas is about $200.0 \mu \mathrm{m}$. Thus the ratio of the outside diameter, the stems up to the thickness of the cortical substance of its dorsal wall and the ventral wall of the median and paired lateral ventral ridges is about $16: 1$.The smallest is the thickness of the cortical substance of the rhachis in the areas of its lateral ventral walls (Fig. 3). The average wall thickness of the rhachis is approximately $50.0 \mu \mathrm{m}$, and the ratio of the outside diameter, the stems up to the thickness of the cortical substance its lateral ventral wall is $65: 1$.

The strength and the elasticity of the stem is caused not only by the thickness of compact substance of its walls and the presence ridges, but also by. Tomography research we have made showed that the brain substance of the stems are heterogeneous in density. Based on tomograms we created a model of the relative positions of the sections of the medulla of the stem with greater and lesser density (Fig. 3). The medulla stems with higher density forms the strands (trabeculae) that go from the cortical substance of the wall of the stem, penetrating its entire thickness. In areas of intersection of such strands or trabeculae clusters are more dense brain matter in formations irregular stellate shape. On the most of the tomograms such clusters are in the center of the stem, forming something of its longitudinal axis. Therefore, the frame of the stem, together with the compact cortex substance of its walls, form a denser portions of his brain matter in the form of interconnected strands (trabeculae) and clusters (Fig. 3).

It should be noted that at first glance, perfectly symmetrical feather really has a lot of homogeneous asymmetric structure. Most should include the branches extending from rhachis flight (remiges and rectrices) feather and with their specific structures form vexillum. In particular of feathers in the branches of the outer and inner webs are placed one opposite the other, epart from the rhachis under different angle. The angle of divergence from the rhachis of the branches of the external webs in the middle part of the remiges feathers of the first and the second order is around $30-35^{\circ}$ and branches of the internal vexillum $-40-45^{\circ}$. Typically, the value of this angle is proportionally the largest in the first (proximal) branches, and the smallest, respectively the last (distal) branches of both external and internal webs that we saw in other bird species (Kostiuk 2015a, b). In addition to unequal angle branches from rhachis branches of the external and internal fans are not on the same level away from the rhachis. As each successive remiges feather wings lays on top of the feather is placed closer to the external (cranial) edge of the wing branches of the outer webs of branching is slightly higher (on average 250.0-300.0 $\mu \mathrm{m}$ ), than the branches inner webs (Fig. 3). The branches of all the varieties of feathers are flattened laterally the cross-sectional shape, unlike the branches down or downy feathers, the cross-sectional shape which is circular except for a small initial segment of them. The height of branches of external and internal large fan of stroke feather of the first and second order in the place of their branch from a stem presents 1200.0-1450.0 $\mu \mathrm{m}$ (Fig. 3). The tip of feathers of all orders formed distal end of the rhachis, which rhachis barbules of the outer vexillum are connected with distal barbules last (distal) branches of the outer webs rhachis and the barbules of the inner vexillum in accordance with distal barbules last branch of inner web. 


\section{CONCLUSIONS}

1. The wing of the domestic goose is founded by 3 feathers: the wing has 10 tail feathers of the first, 17 - second, and 6 of the third order. Tail of domestic goose forms 14 rectrices feathers.

2. A rigid frame of the stem of the investigated feathers form cortex substance and its wall are connected with each other by denim and with the wall of the stem strands by more dense brain matter.

3. The branches of feathers of domestic goose are interconnected not only through fouls, but thin, long, curved ventral ridges, making such connection more durable and impervious to water.

4. The proximal branches of the internal and external webs of the flying feathers have barbs in the form of direct, pointed processes, and the distal branches of both the inner and outer webs have beards of different shapes and in the form of direct, pointed processes, etc.

5. The branches of the outer webs of feathers of domestic goose depart from the rhachis of the feather at a smaller angle and slightly higher than the branches of the inner webs.

\section{REFERENCES}

Baumel J.J., King A.S., Breazile J.E., Evans H.E., Vanden Berge J.C. 1993. Handbook of avian anatomy. Nomina anatomica avium. 2nd ed. Cambridge, Publications of the Nuttall Ornithological Club, 779.

Bulakhov V.L., Novits'kyy R.O., Hasso V.Ya., Pakhomov O.Ye. 2009. Zoologija chordovich [Zoology of chord]. Dnipropetrovsk, [b.w.], 128. [in Ukrainian]

Kostiuk V.K., Voloshchuk O.V. 2015a. Osobennosti stroenija per'ev nekotorych ptic [Features of structure of feathers of some birds]. Hippology Vet. 1(15), 34-40. [in Russian]

Kostiuk V.K., Voloshchuk O.V. 2015b. Osoblivosti budovi pirja paviča zvičajnogo (Pavo cristatus). [Features of structure of feather of peacock ordinary (Pavo cristatus). Vet. Med., Quality and Safety of Products of Stock-Raising 217(1), 83-87. [in Ukrainian]

\footnotetext{
Abstract. It was found out the quantity of rectrices tail feathers and all kinds of remiges wing of domestic goose. There were described the features of macro- and micro-structure and morphometric parameters remiges and rectrices - calamus, pulp case, rachis pennae and barbules pennae. It was established that the medulla rhachis stems are heterogeneous. More dense areas of it together with substance of the rachis of the feathers form the skeleton of the rachis. It is discovered that rami pennae remiges are interconnected with each other not with also only barbules pennae but ventral ridge.
} 
